\title{
Хубецова Залина Федоровна
}

Санкт-Петербургский государственный университет

Россия, 199034, Санкт-Петербург, Университетская наб., 7-9

z.khubetsova@spbu.ru

\section{Российские научно-образовательные школы журналистики как часть мирового научного и образовательного процесса}

Для цитирования: Хубецова З. Ф. Российские научно-образовательные школы журналистики как часть мирового научного и образовательного процесса // Вестник Санкт-Петербургского университета. Язык и литература. 2018. Т.15. Вып. 2. С.312-326. https://doi.org/10.21638/11701/ spbu09.2018.213

Статья посвящена проблеме популяризации российских научно-образовательных школ журналистики как важной части мирового научного и образовательного процесса. На основе анализа мнений представителей ведущих российских вузов, осуществляющих подготовку журналистов, автор делает вывод о корректности применения относительно российской практики исследования журналистики понятия «научно-образовательная школа», так как в России наука о журналистике традиционно развивалась в недрах образовательных учреждений, и о важности популяризации уникального отечественного опыта научно-исследовательской и образовательной деятельности в сфере журналистики. В качестве примера научно-образовательной школы, обладающей такими необходимыми для признания в российской и зарубежной академической среде характеристиками, как наличие устоявшихся направлений научных исследований под руководством известных ученых и с участием известных ученых; образовательных программ по соответствующему профилю; комплексного учебно-методического обеспечения образовательного процесса (учебно-программной и учебно-методической документации); значительного контингента обучающихся; программ аспирантуры и докторантуры и соответствующих научной специальности диссертационных советов; научных журналов, публикующих результаты исследований по соответствующему профилю, рассматривается российская школа политической журналистики. Подробно исследуется вклад Петербургской научно-образовательной школы политической журналистики в развитие отечественного журналистского образования и соответствующей отрасли научных исследований. К числу достижений ученых Высшей школы журналистики и массовых коммуникаций Санкт-Петербургского государственного университета автор относит: разработку понятийного аппарата и определение содержания отрасли научных исследований, посвященных политической журналистике; внедрение в учебные планы подготовки журналистов специальной учебной дисциплины - «Политология журналистики», которая позиционируется как особая разновидность социальных теорий журналистики; открытие программы магистратуры по профилю «Политическая журналистика» и проведение защит кандидатских и докторских диссертаций по научной специальности «Журналистика» с присвоением ученых степеней по политическим наукам; издание учебника для вузов «Политическая журналистика» (с грифом УМО по журналистике) и реализацию научных проектов по соответствующей проблематике, проведение тематических конференций и выпуск сборников научных трудов, посвященных политической журналистике.

(c) Санкт-Петербургский государственный университет, 2018 
Ключевые слова: глобальный научно-образовательный процесс, научно-образовательные школы журналистики в России, Петербургская школа политической журналистики, теория журналистики, интеграция научно-образовательного процесса по журналистике.

\section{Идея популяризации отечественных научно-образовательных школ журналистики в оценках представителей академического сообщества}

В феврале 2017 г. на факультете журналистики МГУ прошла международная научно-практическая конференция «Журналистика в 2016 г.: творчество, профессия, индустрия». Одним из знаковых мероприятий конференции стало заседание секции «Научно-образовательные школы журналистики в России: сегодня и завтра», организованной институтом «Высшая школа журналистики и массовых коммуникаций» (ВШЖиМК) СПбГУ по программе сотрудничества Московского и Петербургского университетов. Участники секции, представлявшие ведущие российские научно-образовательные центры по журналистике, были приглашены к размышлению над следующими дискуссионными вопросами:

- Каковы основания для присвоения статуса научно-образовательной школы?

- Какие направления развития теории журналистики в России можно считать научной школой?

- Что из научного наследия советского прошлого сохраняет свою актуальность и ценность? С чем следует расстаться?

- Какие идеи и труды отечественных исследователей заслуживают признания в мировом научном сообществе?

Автор данных строк как один из организаторов секции и ее постоянный участник имеет уникальную возможность систематизации мнений, высказанных участниками дискуссии в процессе осмысления идеи изучения и популяризации отечественных научно-образовательных школ журналистики. Это позволит определить общие контуры сложившегося в России журналистского исследовательского дискурса и успешно вписать в него знания о российской школе политической журналистики, которой, собственно, и посвящена данная статья.

Принципиальное замечание о состоятельности идеи описания и популяризации научно-образовательных школ журналистики в России было высказано профессором СПбГУ В. А. Сидоровым. По его мнению, «вопросу о научных школах неизбежно сопутствует другой, к сожалению, все еще возникающий в академической среде, - есть ли наука о журналистике» [Сидоров 2017: 427]. В очередной раз отвергая сомнения скептиков в состоятельности научных претензий журналистики, исследователь отмечает:

«Существует не только научное знание о журналистике, то есть ее анализ со стороны филологии, истории, философии и пр., но и научная самоидентификация журналистики $<\ldots>$. Наука о журналистике, если дистанцироваться от внутридисциплинарного / межкафедрального дробления, выступает в единстве двух начал - истории и теории журналистики» [Сидоров 2017: 427]. 
Утвердительно ответив на вопрос о наличии у журналистики статуса самостоятельной отрасли научного знания и описав структуру этого знания, ученый тем не менее подчеркнул неоднозначность трактовки вопроса о научных школах:

«...наличие научных школ в журналистике не выглядит несомненным, потому что небезызвестная зависимость медийной практики от социально-политической тектоники все же позволяет задаваться вопросом, насколько возможна преемственность в теории дисциплины, которая призвана обеспечивать формирование изменчивых профессиональных параметров журналистской деятельности» [Сидоров 2017: 427-428].

Иную точку зрения высказал еще один исследователь из СПбГУ, профессор С.Г.Корконосенко: «Существование в России научно-образовательных школ журналистики не вызывает сомнений» [Корконосенко 2017: 419]. Ученый подчеркнул, что применительно к российской практике корректнее говорить не о научных, а именно о научно-образовательных школах журналистики. Этому есть логическое объяснение:

«Для нашей страны характерно рассматривать симбиоз науки и образования, поскольку традиционно наука развивается на университетских кафедрах, а не в автономных исследовательских институтах, подобных, например, Institute of Communications Research У.Шрамма в США» [Корконосенко 2017: 419].

Какие структурные образования могут претендовать на звание научно-образовательных школ - вот один из главных вопросов, на который, по мнению Корконосенко, нужно дать непротиворечивый ответ. Ученый подчеркивает:

«Ошибкой было бы соотносить их (научно-образовательные школы. - 3.Х.) с учебными заведениями в целом или факультетами, как это нередко происходит. С одной стороны, наличие организации и штата сотрудников само по себе не обеспечивает достижения высоких научных результатов и их признания исследовательским сообществом. С другой стороны, на статус школы могут претендовать отдельные кафедры или даже внутри- или внекафедральные коллективы» [Корконосенко 2017: 420].

Атрибутами научно-образовательных школ, подчеркнул Корконосенко, можно считать: устоявшиеся направления научных исследований под руководством известных ученых и с участием известных ученых; соответствующие профилю образовательные программы, имеющие учебно-методическое обеспечение (учебники и учебные пособия); значительный контингент обучающихся; программы аспирантуры и докторантуры, соответствующие научной специальности диссертационные советы; научные журналы.

Другие участники дискуссии в своих выступлениях продемонстрировали понимание научно-образовательных школ как научное и педагогическое наследие и целых факультетов, и отдельных кафедр, и внекафедральных коллективов, занимающихся разработкой четко очерченного круга вопросов.

Например, исследователь из Южного федерального университета профессор Е.В.Ахмадулин провел прямые параллели между отечественными научно-образовательными школами журналистики и образовательными учреждениями: 
«Научно-образовательные школы журналистики в России <...> возникли сравнительно недавно: в 50-е годы прошлого столетия были открыты факультеты в Московском, Ленинградском и Уральском университетах, в 60-е - отделения журналистки в Дальневосточном, Воронежском и Ростовском университетах. Формату научно-образовательной школы <...> соответствовали только факультеты журналистики МГУ и ЛГУ» [Ахмадулин 2017: 413].

Анализируя актуальное состояние отрасли, ученый подчеркнул:

«...лучшие научно-образовательные школы журналистики (МГУ, СПбГУ) находятся в поиске новой образовательной парадигмы, ориентированной на спрос работодателей и технологические новации» [Ахмадулин 2017: 414].

Также институциональный принцип формирования научно-образовательных школ журналистики представила в своем докладе профессор из Байкальского государственного университета И.Н. Демина. По ее мнению, в Восточной Сибири в настоящее время идет формирование самобытной научно-образовательной школы, частью которой является научно-образовательная деятельность Байкальского государственного университета [Демина 2017: 418].

Идея поиска новой образовательной парадигмы и сохранения научных традиций в профессиональной подготовке журналистов нашла свою развернутую трактовку в выступлении профессора СПбГУ М. А. Бережной:

«Усиление прагматических аспектов в университетском журналистском образовании, ориентация на текущие потребности работодателей, разделение исследовательской и практической составляющей в деятельности преподавателей способствуют разрушению многолетних содержательных и организационных связей теории и практики журналистики, которые являются основой формирования и жизнеспособности научно-образовательной школы. Феномен такой школы составляют единое понимание коллективом профильной кафедры целей и принципов подготовки журналистов, взаимосвязь приоритетных научных направлений и методических разработок, системность, преемственность образовательных программ, постоянная публичная и практическая апробация результатов подготовки» [Бережная 2017: 414].

По мнению ученого, именно профильные кафедры могут претендовать на роль флагманов в формировании научно-образовательных школ. Одну из таких школ - школу кафедры телерадиожурналистики (радио и телевидения) СПбГУ, которая формировалась в активном взаимодействии с Ленинградской студией ТВ и Ленинградским радио, - и представляет сама Бережная.

Примеры развития научно-образовательных школ журналистики внекафедральными научными коллективами были приведены исследователем из Белгородского госуниверситета профессором А.П. Короченским. К настоящему времени, по оценкам ученого, «оформилось основное направление научных исследований <..>: дискурсология и медиакритика современных средств массовой информации» [Короченский 2017: 421]. Также внекафедральный принцип формирования российских научно-образовательных школ поддержали исследователи из СПбГУ И.Н.Блохин (представил социологическое направление в изучении и преподавании журналистики [Блохин 2017: 416]), А.Н.Гришанина (высказалась в поль- 
зу оформления в теории журналистики особого направления, основанного на психологическом изучении журналистики [Гришанина 2017: 417]), Т.И. Краснова (описала направление медиадискурсивных исследований как компонент российской теории журналистики [Краснова 2017: 422]) и др.

К сожалению, ограниченный формат мероприятия не позволил обсудить все аспекты заявленной организаторами проблемы. Именно поэтому, как видно из проведенного анализа, сами идеи, составляющие суть научно-образовательных школ, имена исследователей, возглавляющих значимые научные направления, перспективы сотрудничества с зарубежными исследователями и методы популяризации достижений российской науки о журналистике за рубежом остались за рамками дискуссии. Главным итогом работы секции можно считать достижение представителями ведущих отечественных центров подготовки журналистов консенсуса по вопросу о наличии в России уникальных научно-образовательных школ, которые могли бы обогатить мировую науку, и о необходимости проведения целенаправленной работы по их описанию и популяризации, ибо «российские специалисты самым активным образом участвовали в формировании научного знания о прессе и нередко шли по непроторенным путям» [Корконосенко 2016].

\section{История становления и концептуальные основания российской научно-образовательной школы политической журналистики}

К числу научных направлений, по которым отечественные исследователи «шли непроторенными путями», можно отнести политическую теорию прессы. Сила этой теории объясняется тем, что для российской социальной практики политический аспект функционирования прессы долгое время был определяющим. Советская власть, считавшая организацию печати делом государственной важности, сумела поднять престиж журналистики на невиданную ранее высоту. «Большевики первыми в истории ввели газету и радио действительно в общенациональный государственный оборот посредством всеобей подписки и электрификации всей страны» [Пешков 1999: 344], поэтому и профессиональной подготовке журналистов уделялось много внимания.

Известно, что в СССР первые специализированные журналистские учебные заведения были открыты в 1930-х годах. Подготовка журналистов в вузах стала осуществляться в 1940-х годах [Корконосенко 2004: 18]. А уже в 1949 г. появилась первая в стране аспирантура по научной специальности «Журналистика» - подготовку научных кадров по журналистике стало осуществлять отделение журналистики филологического факультета Ленинградского университета им. А. А. Жданова.

Если за рубежом (в первую очередь в США) журналистское образование носило практико-ориентированный характер, а в исследованиях деятельности прессы доминировали прагматические аспекты, то в СССР существовала традиция концептуального осмысления роли и назначения прессы. Теория советско-партийной печати стала отражением взглядов на прессу К. Маркса, Ф. Энгельса и В. Ленина и обусловленной этими взглядами социальной практики. 
Первые работы по систематизации наследия классиков марксизма-ленинизма появились в середине 1950-х годов. В ЛГУ теоретические основы изучения роли журналистики как фактора политической борьбы и участника политико-властных отношений были заложены в трудах А.Ф. Бережного [Бережной 1956; 1960], а в МГУ - С. М. Гуревича [Гуревич С. М. 1958]. Характерно, что истоки отечественной политической теории журналистики были погружены в глубокий исторический контекст, и лишь в середине следующего десятилетия стали формулироваться исследователями в явном виде (см., например: [Бережной 1966]).

В 1960-1970-х годах общая теория журналистики получила в своем развитии настолько сильный импульс, что стала претендовать на самостоятельный и независимый от истории журналистики научный статус. Связано было это с важными изменениями социальной среды журналистики. К тому времени идея использования печати как орудия классовой борьбы стала терять свою актуальность. Именно поэтому советские исследователи журналистики ощутили потребность в четком постулировании теоретических основ журналистики и приведении теории в соответствие с реальной журналистской практикой.

Как отклик на эту потребность в ведущих вузах страны стали происходить знаковые реорганизации. Так, в 1961 г. отделение журналистики при филологическом факультете ЛГУ получило статус самостоятельного факультета, в структуре которого действовали две кафедры: истории русской журналистики и теории и практики партийно-советской печати. Спустя два года была поделена и кафедра партийно-советской печати факультета журналистики МГУ. С этого времени разработкой теоретических вопросов журналистики стала заниматься кафедра теории и практики партийно-советской печати, а традиционная историческая проблематика отошла к кафедре истории партийно-советской печати.

В 1966 г. при кафедре теории и практики партийно-советской печати МГУ была создана социологическая группа, главной задачей которой стало проведение прикладных социологических исследований. В течение последующих десятков лет ученые факультета журналистики Московского университета (В.М.Горохов, П.С. Гуревич, Я.Н. Засурский, Е.П.Прохоров, Л.Г.Свитич, М.В.Шкондин и др.) и социологический центр занимались разработкой общей теории журналистики и изучением журналистской практики и стали лидирующим научным центром в СССР.

Осмысление теоретических вопросов и освоение методологии прикладных исследований потребовали обращения к зарубежному опыту. Поэтому в 1960-1970-х годах появилось большое количество публикаций, благодаря которым в советский научный оборот была введена проблематика американской социологии массовой коммуникации [Гуревич П. С. 1975; Мансуров 1976; Терин, Шихарев 1975; Шерковин 1967 и др.]. Также на русский язык были переведены труды зарубежных исследователей, предпринимавших в 1950-х годах попытки теоретического осмысления феномена журналистики. Так как по идеологическим соображениям прямой ввод в науку чуждых советскому строю и враждебных коммунизму теорий был недопустим, массово-коммуникационная и теоретико-журналистская проблематика была представлена в форме критического анализа (см.: [Современные буржуазные теории 1967; Буржуазные теории 1980]). Для публикации основных трудов исследователей журналистики в МГУ в 1966 г. была учреждена специальная серия «Журнали- 
стика» научного журнала «Вестник Московского государственного университета». Заметим, что в ЛГУ собственная площадка для публикации научных результатов была создана гораздо раньше - ею стал раздел журнала «Вестник ЛГУ» (серия «Филология. Востоковедение. Журналистика»), издаваемого с 1946 г.

В 1970-х годах, когда общая теория журналистики обрела отчетливые контуры, в особое направление стало оформляться изучение политических аспектов деятельности прессы. Большинство исследований того времени можно свести к научной проблеме «журналистика как элемент системы политико-властных отношений и институт социального контроля» [Бережной 1970; Журналистика в политической структуре 1975; Кузин 1971; Прохоров 1974; Сафаров 1975; Свитич 1977; Смирнов 1978]. Для описания политико-управленческих процессов применительно к журналистике активно использовалась системно-кибернетическая методология. Механизм участия прессы в социальном управлении описывался как двунаправленный поток информации:

а) от субъекта к объекту управления: оглашая официальные документы и законы, разъясняя политику партии и государства, конкретные государственные и административные указания, решения, журналистика оказывает управляющее воздействие на общество и выступает в качестве канала прямой связи;

б) от объекта управления к субъекту: журналистика предоставляет людям возможность для выражения своего мнения по многим актуальным вопросам, оказывая корректирующее воздействие на государство и выступая в качестве канала обратной связи.

Эта схема носила универсальный характер и позволяла рассматривать журналистику в качестве канала прямой и обратной связи:

«1) между обществом и его политической организацией; 2) между институтами политической организации общества; 3) между отдельным институтом как субъектом управления и его объектом; 4) внутри отдельного института» [Журналистика в политической структуре 1975: 37].

Система советской политической теории журналистики рухнула под ударом социально-политических преобразований перестроечного периода. Преобразование журналистской практики под влиянием системной трансформации государства сопровождалось, с одной стороны, деидеологизацией научного знания о политической журналистике, с другой - вестернизацией системы журналистского образования. В обществе развернулись широкие дискуссии о ценности журналистики как института либеральной демократии (в противовес концепции социалистической демократии, доминировавшей в исследовательском дискурсе СССР с 1970-х годов), а в широкий научный оборот было введено множество классических и современных трудов зарубежных исследователей по указанной проблематике. Например, в 1992 г. при содействии Информационного агентства США (USIA) впервые была переведена на русский язык и опубликована знаменитая книга «Демократия в Америке» французского государственного деятеля, историка и литератора Алексиса де Токвиля, в которой рассмотрению роли журналистики в демократической политической системе отведена специальная глава - «О свободе печати в Соединенных Штатах». А в 1998 г. (также при поддержке Информационного агентства США, при участии Института «Открытое общество») был осуществлен перевод на русский 
язык и опубликован еще один классический зарубежный труд, посвященный рассмотрению вопросов политического функционирования прессы в странах с разными моделями политического устройства - «Четыре теории прессы» Фреда С. Сиберта, Уилбура Шрамма и Теодора Питерсона. В списке переведенных на русский язык книг — «Монополия средств информации» Б. Багдикяна (1987); «Общественное мнение. Открытие спирали молчания» Э. Ноэль-Нойман (1996); «Делать мнение. Новая политическая игра» П. Шампаня (1997) и др. Таким образом, российская теория политической журналистики активно осваивала мировой теоретический опыт и пыталась адаптировать рациональное зерно советского теоретического наследия к современным реалиям. С этими задачами российское академическое сообщество справилось лишь к началу 2000-х годов - именно в это время появились первые деидеологизированные труды монографического характера, посвященные теории и практике политической журналистики [Корконосенко 2004].

\section{Петербургская научно-образовательная школа политической журналистики}

Период с 2000-х годов и до настоящего времени можно считать этапом концептуализации политической теории журналистики. Развитие данного проблемно-тематического направления науки о журналистике достигло такого уровня, что его можно считать ядром российской теории журналистики. В пользу данного утверждения свидетельствует следующее:

«1. Четко определены содержание и область исследований данного сегмента теории журналистики. В самом общем виде политическую теорию прессы можно представить как совокупность теоретических взглядов на место прессы в политической системе общества, на характер политического функционирования журналистики и политические отношения, в которые она вступает.

2. Доминирование на том или ином историческом этапе конкретной политической теории имеет наиболее явственные последствия для журналистской практики. Теоретические взгляды на назначение прессы в политической сфере напрямую влияют на качество социальной среды СМИ. Правила, регламентирующие деятельность в политической журналистике, осознаются всеми участниками массово-информационных процессов.

3. Концептуальная система политической теории журналистики может быть описана рядом общеизвестных первичных концептов и проблем, составляющих суть теории. Свобода слова и свобода печати в контексте политических прав и свобод человека и гражданина, политизация медиа; медиатизация политики; медиаполитическая система, медиакратия - вот лишь небольшой перечень понятий и явлений из мира политической журналистики, изучению которых посвящено большое количество научных трудов.

4. Хорошо известны имена политических деятелей, теоретические взгляды которых определили особенности политического функционирования журналистики (К. Маркс, Ф.Энгельс, В. Ленин, современные политические лидеры КНР и т.д.)» [Хубецова 2016: 114].

К формату научно-образовательной школы наиболее приближена работа коллектива исследователей и преподавателей кафедры теории журналистики и мас- 
совых коммуникаций (С. Г.Корконосенко, И.Н.Блохин, В.А.Сидоров, З.Ф.Хубецова др.) и других подразделений ВШЖиМК СПбГУ. С начала 2000-х годов в СПбГУ ведется преподавание специальной теоретической дисциплины - «Политология журналистики», которая позиционируется как особая разновидность социальных теорий журналистики; осуществляется подготовка обучающихся по магистерской программе «Политическая журналистика»; реализуются научные проекты по соответствующей проблематике ${ }^{1}$. В 2015 г. был издан коллективный учебник для вузов «Политическая журналистика» (под редакцией Корконосенко, с грифом УМО). Под руководством сотрудников СПбГУ в ВШЖиМК проводятся тематические научные конференции и издаются научные труды [Журналистика в мире политики 2004; 2007; 2008; 2009; 2010; 2011; 2012], диссертационный совет СПбГУ Д 212.232.17 стал первым в России научным центром, присваивающим ученые степени по журналистике по политическим наукам (первая защита состоялась в 2001 г.).

Таким образом, можно говорить о формировании Петербургской научнообразовательной школы политической журналистики, достижения которой вполне заслуживают популяризации как внутри страны, так и за ее пределами. Также представляется очевидной потребность в дальнейшем изучении и продвижении достижений других российских научно-образовательных школ политической журналистики. В том, что эти достижения есть, сомневаться не приходится.

Возвращаясь к вопросу, чем российская научно-образовательная школа политической журналистики может обогатить мировую науку о журналистике и систему образования, можно акцентировать внимание на следующих преимуществах: категориальный аппарат, разработанный в рамках субдисциплины «политология журналистики»; модель вузовской подготовки специалистов; наличие специальной учебной литературы, научных журналов, диссертационных советов, программ докторантуры и аспирантуры, практически не имеющих аналогов за рубежом, но способствующих институционализации данной отрасли науки и образования.

\section{Литература}

Ахмадулин 2017 - Ахмадулин Е. В. "Научно-образовательные школы журналистики: поиски парадигмы”. Журналистика в 2016 году: творчество, профессия, индустрия: сборник материалов междунар. науч.-практич. конф. М.: МедиаМир; Ф-т журналистики Московского гос. ун-та, 2017. C. 413-414.

Бережная 2017 - Бережная М. А. “Научно-образовательные школы в профильной подготовке журналиста”. Журналистика в 2016 году: творчество, профессия, индустрия: сборник материалов междунар. науч.-практич. конф. М.: МедиаМир; Ф-т журналистики Московского гос. ун-та, 2017. C. 414-415.

Бережной 1956 - Бережной А.Ф. К истории партийно-советской печати: Значение работ В. И. Ленина «Заявление редакции „Искры“" и «С чего начать?» в истории и практике партийно-советской печати. Л.: Изд-во Ленинградского гос. ун-та, 1956. 118 с.

Бережной 1960 - Бережной А.Ф. Ленин - создатель партийно-советской печати. Л.: Лениздат, $1960.68 \mathrm{c}$.

${ }^{1}$ В 2013-2014 гг. под руководством С. Г. Корконосенко был реализован проект НИР из внебюджетных средств СПбГУ «Политическая журналистика в современной России: комплексный подход». 
Бережной 1966 - Бережной А.Ф. Печать ленинского типа - высшее достижение демократии: тезисы доклада на заседании Ученого совета ф-та (Ленинград, февраль 1966 г.). Л.: Б. и., 1966.7 с.

Бережной 1970 - Бережной А. Ф. Ленинские принциипы советской печати. Л.: Лениздат, 1970. 137 с.

Блохин 2017 - Блохин И.Н. “Отечественное театроведение в системе источников теории журналистики”. Журналистика в 2016 году: творчество, профессия, индустрия: сборник материалов междунар. науч.-практич. конф. М.: МедиаМир; Ф-т журналистики Московского гос. ун-та, 2017. C. $415-416$.

Буржуазные теории 1980 - Буржуазные теории журналистики: критический анализ. Засурский Я.Н. (ред.). М.: Мысль, 1980. 253 с.

Гришанина 2017 - Гришанина А.Н. "Психологическое изучение журналистики: вчера, сегодня, завтра”. Журналистика в 2016 году: творчество, пробессия, индустрия: сборник материалов междунар. науч.-практич. конф. М.: МедиаМир; Ф-т журналистики Московского гос. ун-та, 2017. C. $417-418$.

Гуревич С. М. 1958 - Гуревич С. М. «Новая Рейнская газета» Карла Маркса и Фридриха Энгельса. М.: Госполитиздат, 1958. 192 с.

Гуревич П. С. 1975 - Гуревич П. С. “Массовая буржуазная пропаганда и злоключения американской социологической теории”. Массовая культура - иллюзии и действительность. М.: Искусство, 1975. С. 208-232.

Демина 2017 - Демина И.Н. “Формирование новой научно-образовательной школы журналистики в Восточной Сибири (опыт Байкальского государственного университета)”. Журналистика в 2016 году: творчество, профессия, индустрия: сборник материалов междунар. науч.-практич. конф. М.: МедиаМир; Ф-т журналистики Московского гос. ун-та, 2017. С. 418-419.

Журналистика в мире политики 2004 - Журналистика в мире политики: исследовательские подходы и практика участия. Корконосенко С. Г. (ред.). СПб.: Изд-во Михайлова В. А., 2004. 446 с.

Журналистика в мире политики 2007 - Журналистика в мире политики: гуманистическое измерение: материалы секционного заседания конф. «Дни Петербургской философии - 2006». Корконосенко С. Г. (ред.). СПб.: Роза мира, 2007. 204 с.

Журналистика в мире политики 2008 - Журналистика в мире политики: Спрос на интеллект: материалы секиионного заседания конф. "Дни Петербургской философии - 2007». Сидоров В. А. (ред.). СПб.: Роза мира, 2008. 223 с.

Журналистика в мире политики 2009 - Журналистика в мире политики: Ответственность перед будущим: материаль секиионного заседания конф. «Дни Петербургской филособии - 2008». Сидоров В. А. (ред.). СПб.: Б. и., 2009. 242 с.

Журналистика в мире политики 2010 - Журналистика в мире политики: Диалоги о свободе: материалы секционного заседания конф. «Дни Петербургской философии - 2009». Блохин И.Н., Корконосенко С. Г. (ред.). СПб.: Б. и., 2010. 184 с.

Журналистика в мире политики 2011 - Журналистика в мире политики: Модель для будущей России: материаль секционного заседания конф. «Дни философии в Петербурге - 2010». Блохин И.Н., Корконосенко С. Г. (ред.). СПб.: Б. и., 2011. 173 с.

Журналистика в мире политики 2012 - Журналистика в мире политики: Ценностный раскол и согласие: материаль круглого стола всероссийского форума с международным участием «Дни филособии в Петербурге - 2011». Блохин И.Н., Корконосенко С. Г. (ред.). СПб.: Б. и., 2012. 284 с.

Журналистика в политической структуре 1975 - Журналистика в политической структуре общества: некоторые проблемы политической организации системы средств массовой информации u пропаганды. Засурский Я.Н. (ред.). М.: Изд-во Московского гос. ун-та, 1975. 334 с.

Корконосенко 2004 - Корконосенко С. Г. Основы журналистики. М.: Аспект Пресс, 2004. 287 с.

Корконосенко 2016 - Корконосенко С. Г. “Теория журналистики в России: новые подходы и научные школы”. Медиа. Информация. Коммуникация. 18, 2016. URL: http://mic.org.ru/18-nomer2016/577-teoriya-zhurnalistiki-v-rossii-novye-podkhody-i-nauchnye-shkoly (дата обращения: 01.07.2017).

Корконосенко 2017 - Корконосенко С. Г. “Научно-образовательные школы и профессиональные идеологии в российской журналистике”. Журналистика в 2016 году: творчество, профессия, индустрия: сборник материалов междунар. науч.-практич. конф. М.: МедиаМир; Ф-т журналистики Московского гос. ун-та, 2017. С. 419-420. 
Короченский 2017 - Короченский А. П. “К новым горизонтам научного познания”. Журналистика в 2016 году: творчество, профессия, индустрия: сборник материалов междунар. науч.-практич. конф. М.: МедиаМир; Ф-т журналистики Московского гос. ун-та, 2017. С. 421-422.

Краснова 2017 - Краснова Т.И. “Направление медиа дискурсивных исследований в России”. Журналистика в 2016 году: творчество, профессия, индустрия: сборник материалов междунар. науч.-практич. конф. М.: МедиаМир; Ф-т журналистики Московского гос. ун-та, 2017. С. 422-423. Кузин 1971 - Кузин В.И. Газета - орган партийного комитета. Л.: Лениздат, 1971.213 с.

Мансуров 1976 - Мансуров В.А. "Из истории социологии массовых коммуникаций в США”. Из истории буржуазной социологии ХІХ-ХХ веков. Андреева Г.Н. (ред.). М.: Изд-во Московского гос. ун-та, 1976. С. 113-134.

Пешков 1999 - Пешков И.В. “Еще раз «Мышление и речь», или О предмете риторики”. Выготский Л. С. Мышление и речь. М.: Лабиринт, 1999. С. 341-347.

Прохоров 1974 - Прохоров Е.П. “Журналистика, информация, управление”. Филологические этюды. Сер. «Журналистика». Вып. 2. Ростов н/Д: Изд-во Ростовского ун-та, 1974. С. 7-20.

Сафаров 1975 - Сафаров Р. А. Общественное мнение и государственное управление. М.: Юридическая литература, 1975. 255 с.

Свитич 1977 - Свитич Л.Г. “Журналист в системе социального управления”. Мастерство журнатиста. Горохов В. М., Пельт В.Д. (ред.). М.: Изд-во Московского гос. ун-та, 1977. С. 189-201.

Сидоров 2017 - Сидоров В. А. “Слышать эпоху и не терять связь времен”. Журналистика в 2016 году: творчество, профессия, индустрия: сборник материалов междунар. науч.-практич. конф. М.: МедиаМир; Ф-т журналистики Московского гос. ун-та, 2017. С. 427-428.

Смирнов 1978 - Смирнов В.П. Советская демократия и печать. М.: Политиздат, 1978. 158 с.

Современные буржуазные теории 1967 - Современные буржуазные теории журналистики. Засурский Я.Н. (ред.). М.: Изд-во Московского ун-та, 1967. 190 с.

Терин, Шихарев 1975 - Терин В., Шихарев П. “Массовая коммуникация как объект социологического анализа”. «Массовая культура» - иллюзии и действительность. М.: Искусство, 1975. C. 208-232.

Хубецова 2016 - Хубецова 3.Ф. "Политическая теория прессы как ядро теоретического знания о журналистике”. Век информации: Журналистика ХХІ века: поиски теоретического обоснования. 1, 2016: 109-116.

Шерковин 1967 - Шерковин Ю. А. “О природе и функциях массовой коммуникации”. Вестник Московского ун-та. Сер. 10: Журналистика. 6, 1967: 41-58.

Статья поступила в редакцию 7 июня 2017 г. Статья рекомендована в печать 3 октября 2017 г.

\section{Khubetcova Zalina Feodorovna}

St. Petersburg State University

7-9, Universitetskaya nab., St. Petersburg, 199034, Russia

z.khubetsova@spbu.ru

\section{Russian academic schools of journalism as a part of the global research and educational process}

For citation: Khubetcova Z. F. Russian Academic schools of journalism as a part of the global research and educational process. Vestnik of Saint Petersburg University. Language and Literature, 2018, vol. 15, issue 2, pp.312-326. https://doi.org/10.21638/11701/spbu09.2018.213

The article is devoted to the problem of the study and popularization of the Russian research and educational schools of journalism. The analysis was made on the opinions of the representatives of the leading Russian universities that prepare journalists. The author makes a conclusion about the applicability of the concept "research and education school" to the Russian journalism research practice. The author also states the importance of popularization 
of the unique domestic experience of research and educational activities in journalism. The Russian school of political journalism is considered as an example of a research and educational school that possesses the characteristics necessary for recognition in the Russian and international academic environment. It has established research areas under the supervision; educational programmes of the appropriate specialisation; programmes of postgraduate and doctoral studies and corresponding Dissertation Councils; and research journals that publish the results of research in the relevant fields. There is a detailed study of the contribution of the St. Petersburg research and educational school of political journalism to the development of the national journalistic education and the corresponding branch of scientific research. Among the achievements of the researchers of the School of Journalism and Mass Communications of the St. Petersburg State University, the author refers to: development of a conceptual apparatus and definition of the content of the research field devoted to political journalism; introduction of a special academic discipline of the political science of journalism into the curricula of future journalists of; the master's program in "Political Journalism" and defending of the candidate and doctoral dissertations in "Journalism" with the awarding of academic degrees in political science; the publication of a course book "Political Journalism" for high schools; the implementation of research projects on the relevant issues; thematic conferences; and publishing collections of research papers in political journalism.

Keywords: global research and educational process, Russian academic schools of journalism, St. Petersburg school of political journalism, theory of journalism, integration of research and educational process in journalism.

\section{References}

Ахмадулин 2017 - Akhmadulin E.V. "Nauchno-obrazovatel'nye shkoly zhurnalistiki: poiski paradigmy [Scientific and Educational Schools of Journalism: the Search for a Paradigm]". Zhurnalistika v 2016 godu: tvorchestvo, professiia, industriia: sbornik materialov mezhdunar. nauch.-praktich. konf. [Journalism in 2016: Creativity, Profession, Industry: Proceedings of the International Scientific and Practical Conference]. Moscow: MediaMir Publ.; Faculty of Journalism of Moscow State University Press, 2017, pp. 413-414. (In Russian)

Бережная 2017 - Berezhnaia M. A. "Nauchno-obrazovatel'nye shkoly v profil'noi podgotovke zhurnalista [Theoretical and Pedagogical Schools in the Journalism Training]". Zhurnalistika v 2016 godu: tvorchestvo, professiia, industriia: sbornik materialov mezhdunar. nauch.-praktich. konf. [Journalism in 2016: Creativity, Profession, Industry: Proceedings of the International Scientific and Practical Conference]. Moscow: MediaMir Publ.; Faculty of Journalism of Moscow State University Press, 2017, pp. 414-415. (In Russian)

Бережной 1956 - Berezhnoi A. F. K istorii partiino-sovetskoi pechati: Znachenie rabot V. I. Lenina «Zaiavlenie redaktsii „Iskry“» $i$ «S chego nachat'?»v istorii i praktike partiino-sovetskoi pechati [On the History of the Party-Soviet Press: The Significance of Lenin's Works "Statement of the Iskra editorial board" and "Where to start?" in the History and Practice of the Party-Soviet Press]. Leningrad: Leningrad State University Press, 1956. 118 p. (In Russian)

Бережной 1960 - Berezhnoi A. F. Lenin - sozdatel' partiino-sovetskoi pechati [Lenin is the Creator of the Party-Soviet Press]. Leningrad: Lenizdat Publ., 1960. 68 p. (In Russian)

Бережной 1966 - Berezhnoi A. F. Pechat' leninskogo tipa - vysshee dostizhenie demokratii: tezisy doklada na zasedanii Uchenogo soveta f-ta (Leningrad, fevral' 1966 g.) [The Press of the Leninist Type is the Highest Achievement of Democracy: the Theses of the Report at the Meeting of the Academic Council of the Faculty (Leningrad, February 1966)]. Leningrad: No publ., 1966. 7 p. (In Russian)

Бережной 1970 - Berezhnoi A.F. Leninskie printsipy sovetskoi pechati [Leninist Principles of the Soviet Press]. Leningrad: Lenizdat Publ., 1970. 137 p. (In Russian)

Блохин 2017 - Blokhin I.N. "Otechestvennoe teatrovedenie v sisteme istochnikov teorii zhurnalistiki [Russian Theatrical Studies in the System of Sources of the Theory of Journalism]". Zhurnalistika $v$ 2016 godu: tvorchestvo, professiia, industriia: sbornik materialov mezhdunar. nauch.-praktich. konf. 
[Journalism in 2016: Creativity, Profession, Industry: Proceedings of the International Scientific and Practical Conference]. Moscow: MediaMir Publ.; Faculty of Journalism of Moscow State University Press, 2017, pp. 415-416. (In Russian)

Буржуазные теории 1980 - Burzhuaznye teorii zhurnalistiki: Kriticheskii analiz [Bourgeois Theories of journalism: Critical Analysis]. Zasurskii Ia. N. (ed.). Moscow: Mysl Publ., 1980. 253 p. (In Russian)

Гришанина 2017 - Grishanina A.N. "Psikhologicheskoe izuchenie zhurnalistiki: vchera, segodnia, zavtra [Psychological Study of Journalism: Yesterday, Today, Tomorrow]”. Zhurnalistika v 2016 godu: tvorchestvo, professiia, industriia: sbornik materialov mezhdunar. nauch.-praktich. konf. [Journalism in 2016: Creativity, Profession, Industry: Proceedings of the International Scientific and Practical Conference]. Moscow: MediaMir Publ.; Faculty of Journalism of Moscow State University Press, 2017, pp. 417-418. (In Russian)

Гуревич С. M. 1958 - Gurevich S. M. «Novaia Reinskaia gazeta» Karla Marksa i Fridrikha Engel'sa ["The New Rhine Newspaper" by Karl Marx and Friedrich Engels]. Moscow: Gospolitizdat Publ., 1958. 192 p. (In Russian)

Гуревич П. С. 1975 - Gurevich P. S. "Massovaia burzhuaznaia propaganda i zlokliucheniia amerikanskoi sotsiologicheskoi teorii [Mass bourgeois propaganda and the misadventures of American sociological theory]". Massovaia kul'tura - illiuzii i deistvitel'nost' [Mass Culture - Illusions and Reality]. Moscow: Iskusstvo Publ., 1975, pp. 208-232. (In Russian)

Демина 2017 - Demina I.N. "Formirovanie novoi nauchno-obrazovatel'noi shkoly zhurnalistiki v Vostochnoi Sibiri (opyt Baikal'skogo gosudarstvennogo universiteta) [Formation of a New Scientific and Educational School of Journalism in Eastern Siberia (Experience of the Baikal State University)]". Zhurnalistika v 2016 godu: tvorchestvo, professiia, industriia: sbornik materialov mezhdunar. nauch.praktich. konf. [Journalism in 2016: Creativity, Profession, Industry: Proceedings of the International Scientific and Practical Conference]. Moscow: MediaMir Publ.; Faculty of Journalism of Moscow State University Press, 2017, pp. 418-419. (In Russian)

Журналистика в мире политики 2004 - Zhurnalistika v mire politiki: issledovatel'skie podkhody i praktika uchastiia [Journalism in the World of Politics: Research Approaches and Practices of Participation]. Korkonosenko S. G. (ed.). St. Petersburg: Mikhailova V. A. Publ., 2004. 446 p. (In Russian)

Журналистика в мире политики 2007 - Zhurnalistika v mire politiki: gumanisticheskoe izmerenie: materialy sektsionnogo zasedaniia konferentsii «Dni Peterburgskoi filosofii-2006» [Journalism in the World of Politics: The Humanistic Dimension: Proceedings of the Section Session of the Conference "Days of St. Petersburg Philosophy - 2006”]. Korkonosenko S. G. (ed.). St. Petersburg: Roza mira Publ., 2007. 204 p. (In Russian)

Журналистика в мире политики 2008 - Zhurnalistika $v$ mire politiki: Spros na intellekt: materialy sektsionnogo zasedaniia konf. «Dni Peterburgskoi filosofi - 2007» [Journalism in the World of Politics: The Demand for Intelligence: Proceedings of the Section Session of the Conference "Days of Petersburg Philosophy - 2007”]. Sidorov V. A. (ed.). St. Petersburg: Roza mira Publ., 2008. 223 p. (In Russian)

Журналистика в мире политики 2009 - Zhurnalistika v mire politiki: Otvetstvennost' pered budushchim: materialy sektsionnogo zasedaniia konf. «Dni Peterburgskoi filosofi - 2008» [Journalism in the World of Politics: Responsibility for the Future: Proceedings of the Section Session of the Conference "Days of Petersburg Philosophy - 2008”]. Sidorov V. A. (ed.). St. Petersburg: No publ., 2009. 242 p. (In Russian)

Журналистика в мире политики 2010 - Zhurnalistika $v$ mire politiki: Dialogi o svobode: materialy sektsionnogo zasedaniia konf. «Dni Peterburgskoi filosofi - 2009» [Journalism in the World of Politics: Dialogues on Freedom: Proceedings of the Section Session of the Conf. "Days of St. Petersburg Philosophy — 2009”]. Blokhin I. N., Korkonosenko S. G. (eds.). St. Petersburg: No publ., 2010. 184 p. (In Russian)

Журналистика в мире политики 2011 - Zhurnalistika v mire politiki: Model' dlia budushchei Rossii: materialy sektsionnogo zasedaniia konf. "Dni filosofii v Peterburge - 2010» [Journalism in the World of Politics: a Model for the Future of Russia: Proceedings of the Section Session of the "Days of Philosophy in St. Petersburg - 2010”]. Blokhin I. N., Korkonosenko S. G. (eds.). St. Petersburg: No publ., 2011. 173 p. (In Russian)

Журналистика в мире политики 2012 - Zhurnalistika $v$ mire politiki: Tsennostnyi raskol i soglasie: materialy kruglogo stola vserossiiskogo foruma s mezhdunarodnym uchastiem «Dni filosofii v Peterburge - 
2011» [Journalism in the World of Politics: Value Split and Consent: Proceedings of the Round Table Forum with International Participation "Days of Philosophy in St. Petersburg - 2011"]. Blokhin I. N., Korkonosenko S. G. (eds.). St. Petersburg: No publ., 2012. 284 p. (In Russian)

Журналистика в политической структуре 1975 - Zhurnalistika v politicheskoi strukture obshchestva: nekotorye problemy politicheskoi organizatsii sistemy sredstv massovoi informatsii i propagandy [Journalism in the Political Structure of Society: Some Problems of Political Organization of the Media and Propaganda System]. Zasurskii Ia. N. (ed.). Moscow: Moscow State University Press, 1975. 334 p. (In Russian)

Корконосенко 2004 - Korkonosenko S. G. Osnovy zhurnalistiki [Basics of Journalism]. Moscow: Aspekt Press, 2004. 287 p. (In Russian)

Корконосенко 2016 - Korkonosenko S. G. Teoriia zhurnalistiki v Rossii: novye podkhody i nauchnye shkoly [Theory of Journalism in Russia: New Approaches and Scientific Schools]. Media. Information. Communication. 18, 2016. URL: http://mic.org.ru/18-nomer-2016/577-teoriya-zhurnalistiki-v-rossiinovye-podkhody-i-nauchnye-shkoly (accessed date: 01.07.2017). (In Russian)

Корконосенко 2017 - Korkonosenko S. G. "Nauchno-obrazovatel'nye shkoly i professional'nye ideologii $\mathrm{v}$ rossiiskoi zhurnalistike [Scientific and educational schools and professional ideologies in Russian journalism]". Zhurnalistika v 2016 godu: tvorchestvo, professiia, industriia: sbornik materialov mezhdunar. nauch.-praktich. konf. [Journalism in 2016: Creativity, Profession, Industry: Proceedings of the International Scientific and Practical Conference]. Moscow: MediaMir Publ.; Faculty of Journalism of Moscow State University Press, 2017, pp.419-420. (In Russian)

Короченский 2017 - Korochenskii A.P. "K novym gorizontam nauchnogo poznaniia [To New Horizons of Scientific Knowledge]". Zhurnalistika v 2016 godu: tvorchestvo, professiia, industriia: sbornik materialov mezhdunar. nauch.-praktich. konf. [Journalism in 2016: Creativity, Profession, Industry: Proceedings of the International Scientific and Practical Conference]. Moscow: MediaMir Publ.; Faculty of Journalism of Moscow State University Press, 2017, pp. 421-422. (In Russian)

Краснова 2017 - Krasnova T.I. "Napravlenie media diskursivnykh issledovanii v Rossii [The Direction of Media Discursive Research in Russia]". Zhurnalistika v 2016 godu: tvorchestvo, professiia, industriia: sbornik materialov mezhdunar. nauch.-praktich. konf. [Journalism in 2016: Creativity, Profession, Industry: Proceedings of the International Scientific and Practical Conference]. Moscow: MediaMir Publ.; Faculty of Journalism of Moscow State University Press, 2017, pp. 422-423. (In Russian)

Кузин 1971 - Kuzin V.I. Gazeta - organ partiinogo komiteta [The Newspaper as the Organ of the Party Committee]. Leningrad: Lenizdat Publ., 1971.213 p. (In Russian)

Мансуров 1976 - Mansurov V. A. "Iz istorii sotsiologii massovykh kommunikatsii v SShA [From the History of the Sociology of Mass Communications in the United States]". Iz istorii burzhuaznoi sotsiologii XIX-XX vekov [From the History of Bourgeois Sociology of the $19^{\text {th }}-20^{\text {th }}$ Centuries]. Andreeva G. N. (ed.). Moscow: Moscow State University Press, 1976, pp. 113-134. (In Russian)

Пешков 1999 - Peshkov I. V. "Eshche raz «Myshlenie i rech”, ili O predmete ritoriki [Once Again "Thinking and Speaking", or The Subject of Rhetoric]". Vygotskii L. S. Myshlenie i rech' [Thinking and Speech]. Moscow: Labirint Publ., 1999, pp. 341-347. (In Russian)

Прохоров 1974 - Prokhorov E. P. “Zhurnalistika, informatsiia, upravlenie [Journalism, Information, Management]”. Filologicheskie etiudy. Ser. «Zhurnalistika» [Philological Essays. Journalism]. Issue 2. Rostov on Don: Rostov State University Press, 1974, pp.7-20. (In Russian)

Сафаров 1975 - Safarov R. A. Obshchestvennoe mnenie i gosudarstvennoe upravlenie [Public Opinion and State Administration]. Moscow: Iuridicheskaia literature Publ., 1975. 255 p. (In Russian)

Свитич 1977 - Svitich L. G. “Zhurnalist v sisteme sotsial'nogo upravleniia [Journalist in the System of Social Management]”. Masterstvo zhurnalista [Mastery of a Journalist]. Gorokhov V. M., Pel't V.D. (ed.). Moscow: Moscow State University Press, 1977, pp. 189-201. (In Russian)

Сидоров 2017 - Sidorov V. A. “Slyshat' epokhu i ne teriat' sviaz' vremen” [To Hear the Era and not Lose the Connection of Times]". Zhurnalistika v 2016 godu: tvorchestvo, professiia, industriia: sbornik materialov mezhdunar. nauch.-praktich. konf. [Journalism in 2016: Creativity, Profession, Industry: Proceedings of the International Scientific and Practical Conference]. Moscow: MediaMir Publ.; Faculty of Journalism of Moscow State University Press, 2017, pp. 427-428. (In Russian)

Смирнов 1978 - Smirnov V.P. Sovetskaia demokratiia i pechat' [Soviet Democracy and the Press]. Moscow: Politizdat Publ., 1978. 158 p. (In Russian) 
Современные буржуазные теории 1967 - Sovremennye burzhuaznye teorii zhurnalistiki [Modern Bourgeois Theory of Journalism]. Zasurskii Ia.N. (ed.). Moscow: Moscow State University Press, 1967. 190 p. (In Russian)

Терин, Шихарев 1975 - Terin V., Shikharev P. “Massovaia kommunikatsiia kak ob”ekt sotsiologicheskogo analiza [Mass Communication as an Object of Sociological Analysis]". "Massovaia kul'tura» — illiuzii $i$ deistvitel'nost' [Mass Culture of Illusion and Reality]. Moscow: Iskusstvo Publ., 1975, pp. 208-232. (In Russian)

Хубецова 2016 - Khubetsova Z. F. “Politicheskaia teoriia pressy kak iadro teoreticheskogo znaniia o zhurnalistike [Political Theory of the Press as the Core of Theoretical Knowledge about Journalism]". Vek informatsii: Zhurnalistika XXI veka: poiski teoreticheskogo obosnovaniia [The Age of Information: Journalism of the $21^{\text {th }}$ Century: the Search for a Theoretical Basis]. 1, 2016: 109-116. (In Russian)

Шерковин 1967 - Sherkovin Iu. A. O prirode i funktsiiakh massovoi kommunikatsii [On the Nature and Functions of Mass Communication]. Vestnik Moskovskogo un-ta. Ser. 10: Zhurnalistika [Bulletin of Moscow State University. Ser. 10: Journalism]. 6, 1967: 41-58. (In Russian) 